\title{
Applicability of offshore mooring and foundation technologies for marine renewable energy (MRE) device arrays
}

\author{
Madjid Karimirad \& Kourosh Koushan \\ MARINTEK (The Norwegian Marine Technology Research Institute)
}

\author{
Sam Weller \& Jon Hardwick \& Lars Johanning \\ The University of Exeter
}

\begin{abstract}
The marine renewable energy (MRE) sector is progressing from single device units to device arrays. Currently, the mooring/foundation technologies used in MRE are based on offshore oil/gas industry practices. For MRE arrays to reach commercialization, several issues need to be addressed including the hydrodynamic array layout, electrical infrastructure, operations, maintenance, control, moorings, foundations, installation and logistics. The DTOcean (The Optimal Design Tools for Ocean Energy Arrays) project is aimed at accelerating the industrial development of ocean energy power generation knowledge, and providing design tools for deploying the first generation of wave and tidal energy converter arrays. In this paper, the applicability of offshore mooring/foundation technologies for marine renewable energy (MRE) device arrays are assessed. The paper introduces the criteria which can be used to appraise technologies and approaches relevant to MRE devices. Existing mooring/foundation technologies used in the offshore industry are summarized with examples given of MRE device deployments. The guidance from certification agencies which is used for the design and analysis of mooring/foundation systems is summarized. If not addressed, the failure to optimize the design of ocean energy arrays and failure to properly understand economic, environmental, or reliability impacts of individual components could have significant consequences for the overall project and sector. The function and type of mooring and/or foundation system are determined by a number of factors including the cost, site characteristics, expected environmental loading and environmental or legislative constraints and these factors are discussed.
\end{abstract}

\section{INTRODUCTION}

The purpose of a mooring/foundation system is to provide offshore equipment with a means of stationkeeping that is sufficiently robust to resist environmental loading, impact and operational procedures. Marine renewable energy (MRE) devices represent a relatively recent field of application with specific requirements and challenges. In 2013, the Research Councils UK Energy Programme Strategy Fellowship identified the development of cost effective MRE foundations and support structures for deep water as a 'High-level Research Challenge'. To date a number of wave and tidal energy technologies have been trialed offshore to establish proof of concept, with funding competitions such as the Saltire Prize established to incentivize the MRE industry. Of the concepts which have reached the stage of full-scale prototype testing at sea (Technology Readiness Levels 7-8) most are either single devices or small arrays $(<10$ devices). In order for the MR in- dustry to reach commercial viability, large scale deployments comprising many tens or hundreds of devices are required (Figure 1). Providing robust and economical mooring and foundation systems for a large number of array devices over the lifetime of the project will be a significant challenge to the MRE industry. MRE mooring and foundation assessment comprises several steps as illustrated in Figure 2. The criteria for mooring or foundation assessment will depend on the starting point of the design process and the level of information provided.
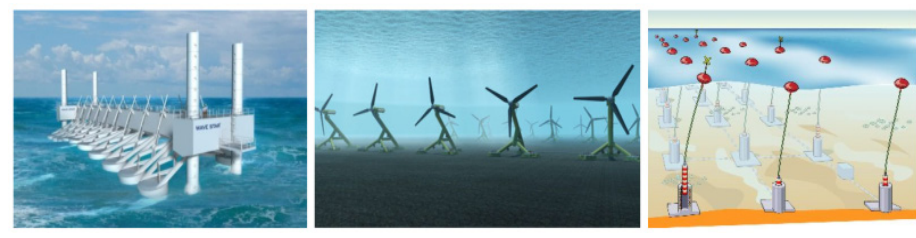

Figure 1. Artist's impressions of MRE arrays: (left) Wave Star wave energy converter (Marquis et al. 2010), (middle) ScottishPower Renewables Sound of Islay 10MW tidal turbine array (Carrell 2011), (right) Uppsala University wave power plant (Astrand 2013) 


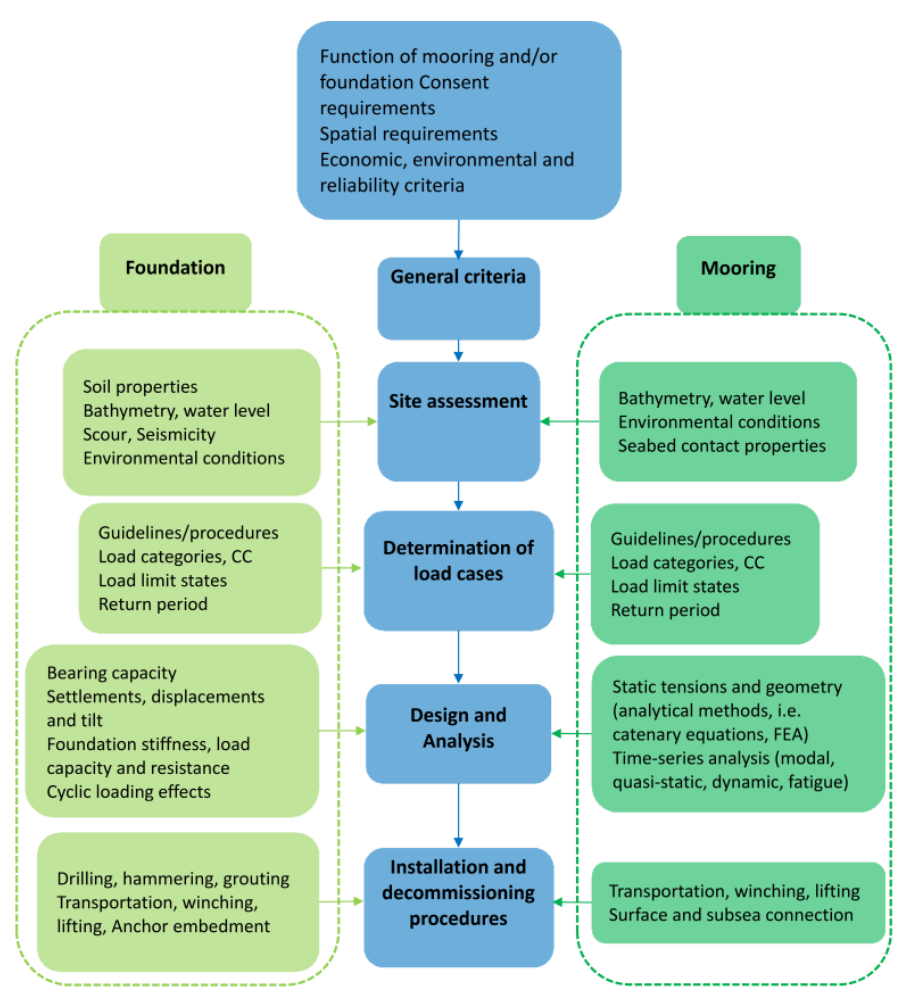

Figure 2. The steps in mooring and foundation assessment; Considerations specific to moorings (dark green) and foundations (light green) are shown. Note: the abbreviation ' $\mathrm{CC}$ ' refers to Consequence Criteria.

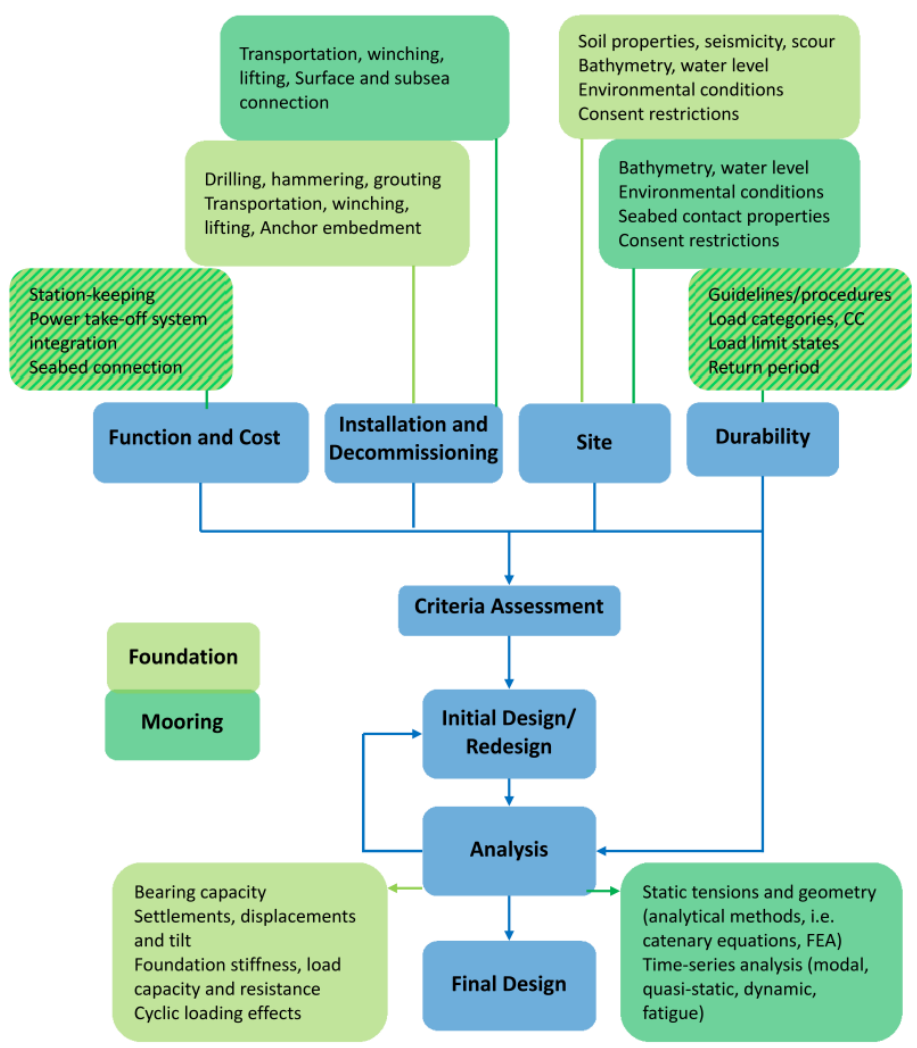

Figure 3. Steps in mooring and foundation design. Considerations specific to moorings (dark green) and foundations (light green) and common requirements (hatched) are shown.

A preliminary study may be conducted in which the MRE device is selected and several site options exist which are dependent on the feasibility and cost of the mooring or foundation. Alternatively, the complete MRE system and site may have already been defined and the selection of mooring or foundation components is required.

The purpose of this document is not only to report on what has already been used for MRE systems, but also to consider the applicability of other offshore mooring and foundation technologies as well as novel designs, with emphasis placed on their suitability for MRE device arrays.

\section{MOORING/FOUNDATION ASSESSMENT}

A general approach to design based on general selection criteria are shown in Figure 3. The design and certification of offshore structures is usually carried out in accordance with guidelines and procedures defined by certification agencies. For insurance underwriting, certification is required to provide evidence that the device has been designed in terms of reliability, survivability and risk control during the lifetime of the device.

\subsection{Function and cost}

The function and capital cost of the foundation system will impact the feasibility of certain choices and may preclude particular systems. Moorings and foundations represent a significant proportion of the overall capital cost of a project and must therefore be within the scope of the project development budget. With array configurations comprising tens or hundreds of devices certain costs are likely to be scalable. It is estimated (LCICG 2012) that mooring and foundation systems account for approximately $10 \%$ of the total cost of energy (Table 1 ).

Table 1. Approximate costs of foundation/mooring in relation to installation, operations and maintenance (O\&M) costs (LCICG 2012)

\begin{tabular}{|l|c|}
\cline { 2 - 2 } \multicolumn{1}{c|}{} & $\begin{array}{c}\text { Cost of Energy } \\
\text { (Wave, Tidal) }\end{array}$ \\
\hline Foundations and moorings & $10 \%, 10 \%$ \\
Installation & $10 \%, 35 \%$ \\
O\&M & $25 \%, 15 \%$ \\
\hline
\end{tabular}

Both function and cost are mutually dependent criteria (SIOCEAN 2013): "Installation of floating tidal devices has different requirements to those with foundations. Replacing a foundation with a set of moorings raises a number of design challenges but allows deeper water, higher resource areas to be accessed. Installation of floating tidal devices or platforms should be significantly cheaper than installation of bottom mounted devices. Equally, installation of floating wave devices is significantly cheaper than installation of bottom-mounted devices." 


\subsection{Installation and Decommissioning}

The installation requirements of different foundation and mooring systems also have a key role to play in the decision making process, including the design of the system and the ease of installation and decommissioning. Ideally at the end of the project lifetime all equipment should be removed and no trace of operations should remain at the site (DECC 2011). However, partial decommissioning may be acceptable if full decommissioning is impractical (Kenny 2010).

\subsection{Site}

Information obtained from a site assessment will inform the design of the mooring or foundation system and the selection of components. Constraints to development (e.g. zoning restrictions, environmental impact and navigational issues) will have been identified at the consenting stage. The spatial distribution of mooring and foundation points for wave and tidal energy devices will be determined by the array layout and the need to provide access space between the devices (i.e. for operations and maintenance activities) and to avoid equipment damage or entanglement (with other mooring lines, water users or wildlife). The Environmental Impact Assessment (EIA) and Strategic Environmental Assessment (SEA) should be documented (EquiMar 2011).

\subsection{Durability}

Over the lifetime of the installation the mooring or foundation system must be able to withstand complex loading conditions to prevent overloading or fatigue. The failure of critical components (i.e. mooring line failure or anchor pull-out) could result in damage of the MRE device and lead to revenue being lost due to operational downtime. For this reason critical failure analysis must be conducted at the design stage. The term durability accommodates both holding capacity and reliability. All components must be functional for the expected system lifetime with sufficient allowances for wear, corrosion or changes to material properties. To ensure the continued functionality of components preventative maintenance must also be planned (e.g. bio-fouling, scour and corrosion mitigation).

In Table 2 criteria which are likely to be analyzed as part of mooring and foundation system assessment are listed. Despite new safety classes being defined in (DNV 2008a) (see Table 3), most of the guidance for moorings and foundations (such as load coefficients) is based on existing DNV offshore standard and recommended practices. It is likely that developments in the MRE industry e.g. the forthcoming International Electrotechnical Commission TC114 guidelines (IEC in-progress) and accumulat- ed offshore experience will shape future guidance and lead to more applicable "factors of safety (FOS)" for components.

Table 2. Typical mooring and foundation system analysis stages. Recommended analysis stages are reported in detail in offshore guidance documents such as API RP 2SK (API 1996), DNV-OS-E301 (DNV 2010), and SP-2209-OCN (NFEC 2012)

\begin{tabular}{|c|c|c|}
\hline $\begin{array}{l}\text { Analysis } \\
\text { type }\end{array}$ & Scope & Method \\
\hline $\begin{array}{l}\text { Static } \\
\text { (mooring) }\end{array}$ & $\begin{array}{l}\text { Pretension of the sys- } \\
\text { tem, mooring geome- } \\
\text { try, device draft }\end{array}$ & $\begin{array}{l}\text { Geometric approximations } \\
\text { based on static parameters }\end{array}$ \\
\hline $\begin{array}{l}\text { Quasi-static } \\
\text { (mooring) }\end{array}$ & $\begin{array}{l}\text { Maximum line ten- } \\
\text { sions and mooring ge- } \\
\text { ometry and stiffness } \\
\text { based on expected off- } \\
\text { sets }\end{array}$ & $\begin{array}{l}\text { Load calculation at several } \\
\text { fairlead position offsets (de- } \\
\text { vice and mooring dynamics } \\
\text { neglected) }\end{array}$ \\
\hline $\begin{array}{l}\text { Dynamic } \\
\text { (mooring) }\end{array}$ & $\begin{array}{l}\text { Maximum line ten- } \\
\text { sions and mooring ge- } \\
\text { ometry of the moored } \\
\text { system subjected to } \\
\text { external loading }\end{array}$ & $\begin{array}{l}\text { Inclusion of inertia, stiff- } \\
\text { ness, damping and fluid ex- } \\
\text { citation force terms. Fre- } \\
\text { quency domain, time } \\
\text { domain and combined } \\
\text { methods exist }\end{array}$ \\
\hline $\begin{array}{l}\text { Fatigue } \\
\text { (mooring) }\end{array}$ & $\begin{array}{l}\text { Calculation of fatigue } \\
\text { damage through cyclic } \\
\text { loading }\end{array}$ & $\begin{array}{l}\text { Failure probability analysis } \\
\text { (i.e. rainflow counting } \\
\text { methods), S-N curves, finite } \\
\text { element analysis, fracture } \\
\text { mechanics }\end{array}$ \\
\hline $\begin{array}{l}\text { Modal } \\
\text { (mooring) }\end{array}$ & $\begin{array}{l}\text { Axial and transverse } \\
\text { mode shape and reso- } \\
\text { nance analysis }\end{array}$ & $\begin{array}{l}\text { Non-linear time domain } \\
\text { analysis }\end{array}$ \\
\hline \multirow{5}{*}{$\begin{array}{l}\text { Static and } \\
\text { Dynamic } \\
\text { (Foundation) }\end{array}$} & Drag embedment & $\begin{array}{l}\text { Analytical techniques to de- } \\
\text { termine: tripping and pene- } \\
\text { tration, stability and holding } \\
\text { capacity }\end{array}$ \\
\hline & Suction & $\begin{array}{l}\text { Analytical and finite ele- } \\
\text { ment techniques to deter- } \\
\text { mine: holding capacity, pen- } \\
\text { etration depth, adhesion } \\
\text { factor, bearing capacity, un- } \\
\text { der pressure, soil plug heave }\end{array}$ \\
\hline & Driven pile & $\begin{array}{l}\text { Geotechnical and structural } \\
\text { strength analysis to deter- } \\
\text { mine: pile loads, penetration }\end{array}$ \\
\hline & Gravity anchor & $\begin{array}{l}\text { Analytical and finite ele- } \\
\text { ment techniques to deter- } \\
\text { mine: bearing and lateral } \\
\text { loading capacities as well as } \\
\text { foundation settlement }\end{array}$ \\
\hline & Plate anchor & $\begin{array}{l}\text { Analytical and finite ele- } \\
\text { ment techniques to deter- } \\
\text { mine: holding capacity, pen- } \\
\text { etration depth and keying }\end{array}$ \\
\hline
\end{tabular}

The likely consequence of mooring system failure for a MRE device will be comparatively less severe than for the types of large offshore equipment. Possible consequences include: the leakage of internal fluids, beaching or collision of devices/other marine craft or species. Therefore it could be argued that the FOS specified in existing offshore guidelines are unnecessarily onerous, with the associated costs hav- 
ing a significant impact on the cost of the project. Recently it has been suggested that guidelines produced for other offshore equipment which are only manned for short intervals during their operational lifetime (e.g. fish farms) may have more relevance (Paredes et al. 2013).

Table 3. Safety levels as defined by the DNV-OSS-213: Certification of Tidal and Wave Energy Converters guidelines (DNV 2008b)

\begin{tabular}{l|l}
\hline Safety Level & \multicolumn{1}{c}{ Definition } \\
\hline Low & $\begin{array}{l}\text { Where failure implies low risk of human injury and } \\
\text { minor environmental and economic consequences. }\end{array}$ \\
\hline Normal & $\begin{array}{l}\text { For temporary conditions where failure implies risk } \\
\text { of human injury, significant environmental pollution } \\
\text { or high economic, asset damage or political conse- } \\
\text { quences. This level normally aims for a risk of less } \\
\text { than 10-4 per year of a major single accident, which } \\
\text { corresponds to a major incident happening on aver- } \\
\text { age less than once every 10,000 installation years. } \\
\text { This level equates to the experience level from major } \\
\text { representative industries and activities. }\end{array}$ \\
\hline High & $\begin{array}{l}\text { For operating conditions where failure implies high } \\
\text { risk of human injury, significant environmental pol- } \\
\text { lution or very high economic or political conse- } \\
\text { quences. }\end{array}$ \\
\hline
\end{tabular}

\section{TECHNOLOGIES}

The development of offshore mooring systems and foundations is linked to the trend of oil and gas exploration in increasing water depths, necessitating a departure from fixed to floating structures. The design objectives of the MRE industries differ with concepts likely to be placed in intermediate water depths (shallow to deep). In the offshore oil and gas industry, cost has a lower priority compared to other aspects such as time scale, reliability and safety (Karimirad 2011). Although much useful knowledge can be gained from the experience of existing offshore industries, the design methods used may need to be modified for the MRE industry.

There is usually strong coupling between the device and mooring system responses (Johanning et al. 2007) and potentially large, resonant motions can occur. Unlike existing offshore equipment which is designed to avoid such responses, wave energy converters (WECs) tend to be designed to maximize power extraction under such conditions in one or more modes of motion. Therefore the mooring and anchoring systems of WECs have to be sufficiently durable (in terms of fatigue and capacity) to sustain cyclic loading and significant peak loads.

\subsection{Moorings}

MRE mooring systems can be divided into three categories; passive, active and reactive. The main function of a passive mooring system is to provide station-keeping only. These systems tend to be used for large floating platforms which support multiple MRE devices. In addition to providing stationkeeping, the response of active mooring systems has a significant influence on the dynamic response of the moored device, to the extent that both responses are coupled and hence affect the power output of the device. Many of the proposed wave energy converter designs fit into this category, including the Pelamis Wave Power's P2 device. In the case of a reactive system the mooring is an integral part of the system, perhaps linking the floating part of a wave energy converter (WEC) to the power take-off e.g. Carnegie Wave Energy's CETO device (Vicente et al. 2012). Several variants exist (as illustrated in Figure 4, with advantages and disadvantages listed in Table 4), (Harris et al. 2004).

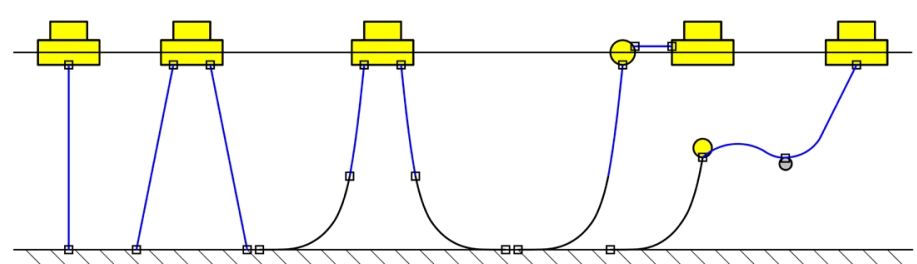

Figure 4. Schematic of possible mooring arrangements for a single MRE device: (from left) taut-moored systems with single and multiple lines, basic catenary system, catenary system with auxiliary surface buoy and lazy-wave system with subsea floater and sinker. The combined use of synthetic ropes and chains (blue and black lines respectively) may be feasible to reduce peak loads and provide compliance

Both catenary and taut moored systems are widely used in the offshore industry, particularly for floating production storage and offloading (FPSO), floating production storage (FPS) facilities as well as Single Point mooring and Reservoir (SPAR) and Catenary Anchor Leg Mooring (CALM) structures. Other categories of moorings include: Single Anchor Leg Mooring (SALM), Articulated Loading Column (ALC) and Fixed Tower Mooring systems. In terms of device scale, geometry and mass, the CALM buoy (Cozijn and Bunnik 2004) has perhaps the closest similarities with large buoy-like MRE devices. The majority of CALM buoys have been used for tanker loading in coastal locations. Catenary mooring systems comprise single or multiple lines with a catenary geometry to provide the necessary horizontal and vertical restoring forces to keep a device on station whilst allowing for changes in the water depth due to tidal variations. For MRE devices the compliance of a catenary system allows motions in several degrees-of-freedom for power generation. The horizontal compliance of a catenary mooring 
system can be increased by 'lazy-wave' system which includes float and sinker components attached to the line.

Table 4. Features of common mooring types

\begin{tabular}{|c|c|c|}
\hline Configuration & Advantages & Disadvantages \\
\hline $\begin{array}{l}\text { Single line } \\
\text { (Taut) }\end{array}$ & $\begin{array}{l}\text { Can provide a direct } \\
\text { link between the float- } \\
\text { ing part and PTO sys- } \\
\text { tem; } \\
\text { Few components (cost } \\
\text { and reliability impli- } \\
\text { cations) }\end{array}$ & $\begin{array}{l}\text { No redundancy is provided } \\
\text { in the case of line failure; } \\
\text { Not suitable for large tidal } \\
\text { ranges (unless the floating } \\
\text { part can be submerged); } \\
\text { Anchors and foundations } \\
\text { that can be loaded vertically } \\
\text { are required }\end{array}$ \\
\hline $\begin{array}{l}\text { Multiple lines } \\
\text { (Taut) }\end{array}$ & $\begin{array}{l}\text { Redundancy is pro- } \\
\text { vided; } \\
\text { Allows the specifica- } \\
\text { tion of lower capacity } \\
\text { components than a } \\
\text { single taut line system } \\
\text { as tensions are shared; } \\
\text { Mooring system foot- } \\
\text { print is usually smaller } \\
\text { than for catenary; } \\
\text { Horizontal restoring } \\
\text { forces tend to be high- } \\
\text { er than for catenary } \\
\text { systems }\end{array}$ & $\begin{array}{l}\text { A significant tidal range } \\
\text { may necessitate a large } \\
\text { mooring footprint (unless } \\
\text { the floating part can be } \\
\text { submerged); } \\
\text { Anchors and foundations } \\
\text { that can be loaded vertically } \\
\text { are required; } \\
\text { More components (cost and } \\
\text { reliability implications) }\end{array}$ \\
\hline $\begin{array}{l}\text { Single line } \\
\text { (Catenary) }\end{array}$ & $\begin{array}{l}\text { Compliance that is } \\
\text { provided by mooring } \\
\text { geometry may mean } \\
\text { lower peak loads than } \\
\text { a taught system; } \\
\text { Suitable for large tidal } \\
\text { range sites; } \\
\text { Wider range of anchor } \\
\text { and foundation op- } \\
\text { tions are suitable; } \\
\text { Few components } \\
\text { (cos/reliability impli- } \\
\text { cations) }\end{array}$ & $\begin{array}{l}\text { No redundancy is provided } \\
\text { in the case of line failure; } \\
\text { The floating part of the de- } \\
\text { vice may be capable of large } \\
\text { horizontal motions which } \\
\text { could have clearance impli- } \\
\text { cations for device arrays }\end{array}$ \\
\hline $\begin{array}{l}\text { Multiple lines } \\
\text { (Catenary) }\end{array}$ & $\begin{array}{l}\text { Redundancy is pro- } \\
\text { vided; } \\
\text { Allows the specifica- } \\
\text { tion of lower capacity } \\
\text { components than a } \\
\text { single taut line system } \\
\text { as tensions are shared }\end{array}$ & $\begin{array}{l}\text { More components (cost and } \\
\text { reliability implications); } \\
\text { Risk of line entanglement } \\
\text { with adjacent devices in ar- } \\
\text { rays }\end{array}$ \\
\hline $\begin{array}{l}\text { With surface } \\
\text { buoy } \\
\text { (Catenary) }\end{array}$ & $\begin{array}{l}\text { Horizontal peak loads } \\
\text { lower than normal ca- } \\
\text { tenary and taut- } \\
\text { mooring systems }\end{array}$ & $\begin{array}{l}\text { More components (cost and } \\
\text { reliability implications); } \\
\text { Surface buoy will be sub- } \\
\text { jected to wind and current } \\
\text { loading }\end{array}$ \\
\hline $\begin{array}{l}\text { Lazy-wave } \\
\text { (Catenary) }\end{array}$ & $\begin{array}{l}\text { Horizontal peak loads } \\
\text { lower than normal ca- } \\
\text { tenary and taut- } \\
\text { mooring systems }\end{array}$ & $\begin{array}{l}\text { More components (cost and } \\
\text { reliability implications); } \\
\text { Surface buoy will be sub- } \\
\text { jected to wind and current } \\
\text { loading }\end{array}$ \\
\hline
\end{tabular}

Although it is possible to use steel components (wires and chains) for the entire length of the line, alternative materials (i.e. synthetic ropes) could be used for the mid or upper sections of the line to reduce the cost and weight of mooring system and provide compliance. 'Rider' or 'ground' chains are used for the lower sections to provide tension to the line whilst transferring loads horizontally to the anchor or foundation.

Taut-mooring systems provide a much stiffer connection between the device and seabed, with compliance only provided by the axial properties of the mooring components, such as synthetic ropes. Ropes constructed from polyester (Banfield et al. 2005) have been successfully used for platforms located in deep and ultra-deep water locations. Because both horizontal and vertical restoring forces are provided by this type of mooring system, foundations and anchors must be specified which can operate under both loading directions (usually drag embedment type anchors are not suitable). Unless a large mooring footprint is specified, the limited compliance of a taut-moored system may mean that the device becomes submerged during large amplitude waves or in locations with high tidal ranges. Full or partial submersion of the device is not an issue for some designs and may be a way of limiting device displacements in large amplitude waves (Stallard et al. 2009).

Ropes constructed from synthetic materials such as polyester, aramid, nylon and high-modulus polyethylene have been used successfully for the last two decades in the offshore industry for vessel mooring, towing and equipment station-keeping. One of the most common rope types is parallel stranded polyester. Fibre ropes have particular advantages compared to steel components, including low cost and mass (per unit length) and load-extension properties that can be harnessed to reduce peak loadings. It is feasible that utilization of these materials could reduce the cost of energy of MRE mooring systems. Unlike steel components, synthetic materials have nonlinear load-extension properties that are timedependent (Weller et al. 2014). Changes to the compliance of these materials are possible over the lifetime of the component and this should be factored into the design. For example, after manufacture the initial loading of certain synthetic ropes results in permanent extension and this should be accounted for in the design of mooring systems. Through extensive research over the last 20 years, the fatigue, durability and stiffness of polyester is well understood. Nylon ropes which are 2-3 times more compliant than polyester, could be suitable for MRE mooring systems (Ridge et al. 2010). 


\subsection{Foundations}

MRE foundation systems can be categorized in several ways, such as whether they are temporary or permanent. The main types of foundation are illustrated schematically in Figure 5. An alternative classification is if they form part of a support structure; pile foundations, gravity based structures and suction piles are fitting into this category. Foundations can also provide a means of attachment between the seabed and mooring lines. The relative advantages and disadvantages of different types are listed in Tables $5 \mathrm{a}$ and $5 \mathrm{~b}$.

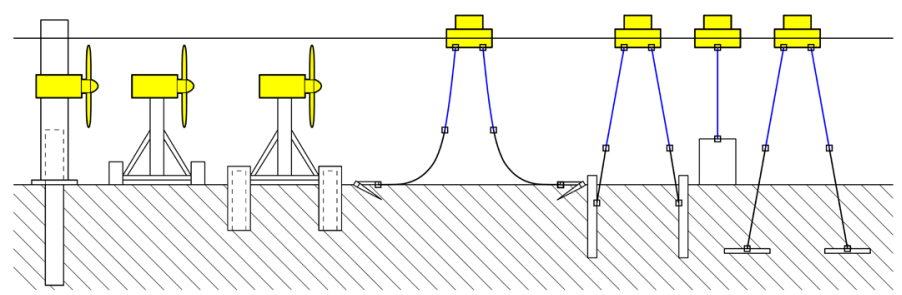

Figure 5. Schematic of possible foundation arrangements for MRE devices: (from left) piled foundation, gravity based structure, suction pile or caisson and several anchor types (fluke, pin pile, gravity and plate)

Table 5a. Features of common foundation types

\begin{tabular}{|c|c|c|}
\hline Type & Advantages & Disadvantages \\
\hline Piled & $\begin{array}{l}\text { Enables high axial loads to } \\
\text { be transmitted through sed- } \\
\text { iments to load bearing rock } \\
\text { or soils; } \\
\text { Can be installed in a wide } \\
\text { range of seabed types; } \\
\text { Well-established, simple } \\
\text { technology }\end{array}$ & $\begin{array}{l}\text { Requires considerable } \\
\text { equipment, expertise and } \\
\text { time for installation. In- } \\
\text { stallation costs are there- } \\
\text { fore high; } \\
\text { Full decommissioning not } \\
\text { possible; } \\
\text { Scour protection measures } \\
\text { may be required; } \\
\text { Not suitable for deep wa- } \\
\text { ter (+30m depth); } \\
\text { Installation noise; }\end{array}$ \\
\hline $\begin{array}{l}\text { Gravity } \\
\text { based }\end{array}$ & $\begin{array}{l}\text { Simple installation recov- } \\
\text { ery procedures are possible } \\
\text { (i.e. float-out to site and } \\
\text { lower to seabed). Installa- } \\
\text { tion costs tend to be low; } \\
\text { Suitable for rock and thin } \\
\text { sediment sites; } \\
\text { Provides a stable structure } \\
\text { for direct attachment of } \\
\text { device }\end{array}$ & $\begin{array}{l}\text { Lateral load resistance low } \\
\text { compared to other founda- } \\
\text { tion types and dependent } \\
\text { on the seabed slope; } \\
\text { Size limited by transporta- } \\
\text { tion and lifting equipment; } \\
\text { May require the installa- } \\
\text { tion of pin piles; } \\
\text { Construction costs are } \\
\text { high }\end{array}$ \\
\hline $\begin{array}{l}\text { Suction } \\
\text { piles or } \\
\text { caissons }\end{array}$ & $\begin{array}{l}\text { Inexpensive installation } \\
\text { (float-out may be feasible); } \\
\text { Easy to remove and possi- } \\
\text { bility of re-use; } \\
\text { Applicable for a wide } \\
\text { range of water depths; } \\
\text { Noise during installation } \\
\text { low compared to piling }\end{array}$ & $\begin{array}{l}\text { Holding capacity in lay- } \\
\text { ered seabed types is un- } \\
\text { clear; } \\
\text { Construction costs may be } \\
\text { high; } \\
\text { Large capacity lifting } \\
\text { equipment may be re- } \\
\text { quired; } \\
\text { Detailed site data required }\end{array}$ \\
\hline
\end{tabular}

Table 5b. Features of common anchor types

\begin{tabular}{|c|c|c|}
\hline Type & Advantages & Disadvantages \\
\hline Fluke & $\begin{array}{l}\text { Well-established tech- } \\
\text { nology; a wide range of } \\
\text { sizes and types are } \\
\text { available; } \\
\text { High holding capacities } \\
\text { are possible; } \\
\text { Can re-set in the event } \\
\text { of pull-out; } \\
\text { Relatively easy to re- } \\
\text { cover }\end{array}$ & $\begin{array}{l}\text { Not suitable for vertical } \\
\text { loading and only suitable for } \\
\text { certain seabed types; } \\
\text { Holding capacity dependent } \\
\text { on seabed continuity (e.g. } \\
\text { scour may cause breakout); } \\
\text { Requires significant mooring } \\
\text { footprint; } \\
\text { Possibility of dragging and } \\
\text { subsequent unequal mooring } \\
\text { system loading; } \\
\text { Possibility of inaccurate } \\
\text { placement during anchor set- } \\
\text { ting }\end{array}$ \\
\hline $\begin{array}{l}\text { Plate/ } \\
\text { Vertical } \\
\text { load an- } \\
\text { chor } \\
\text { (VLA) }\end{array}$ & $\begin{array}{l}\text { High capacity for resist- } \\
\text { ing vertical and lateral } \\
\text { loads; } \\
\text { Possibility of anchor } \\
\text { dragging eliminated; } \\
\text { High holding-capacity- } \\
\text { to-weight ratio than oth- } \\
\text { er anchor types; } \\
\text { Relatively lightweight } \\
\text { for handling; } \\
\text { Accurate placement pos- } \\
\text { sible, no anchor setting } \\
\text { required }\end{array}$ & $\begin{array}{l}\text { Soil properties required for } \\
\text { critical moorings; } \\
\text { Recovery not possible; } \\
\text { May be subject to fatigue or } \\
\text { abrasion; } \\
\text { Installation limitations with } \\
\text { water depth (i.e. for hammer- } \\
\text { driven, screw and vibration } \\
\text { operations) }\end{array}$ \\
\hline Pile & $\begin{array}{l}\text { High vertical lateral } \\
\text { loading capacities possi- } \\
\text { ble; } \\
\text { Anchor dragging and } \\
\text { setting not required; } \\
\text { Enables small mooring } \\
\text { footprint; } \\
\text { Attachment point can be } \\
\text { at seabed level }\end{array}$ & $\begin{array}{l}\text { Requires special equipment } \\
\text { to install and recover; } \\
\text { High quality site data is re- } \\
\text { quired; } \\
\text { Has zero holding capacity } \\
\text { once pull-out starts to occur }\end{array}$ \\
\hline Gravity & $\begin{array}{l}\text { Suitable for rock and } \\
\text { thin sediment sites; } \\
\text { Vertical force compo- } \\
\text { nent can be large; } \\
\text { Construction materials } \\
\text { are usually economical } \\
\text { and readily available; } \\
\text { Can be used as a sinker } \\
\text { in combination with } \\
\text { drag embedment anchors }\end{array}$ & $\begin{array}{l}\text { Size limited by transporta- } \\
\text { tion and lifting equipment; } \\
\text { Lateral load resistance low } \\
\text { compared to other anchor } \\
\text { types and dependent on sea- } \\
\text { bed slope; } \\
\text { Can be an obstruction in } \\
\text { shallow waters }\end{array}$ \\
\hline
\end{tabular}

There is a diverse range of anchor technologies which are available and the selection is largely dependent on the seabed conditions as well as the required holding capacity and load direction. The holding capacity of conventional fluke anchors is dependent on anchor weight, fluke area embedment depth and seabed soil type (usually medium to firm soils). Although readily deployable and recoverable, 
they are not capable of sustaining significant vertical loading. If a vertical load is applied through lifting of the entire mooring line, dislodgement of the anchor may occur leading to partial (or total in the case of single line systems) loss of station-keeping ability. Pile anchors provide lateral and vertical holding capacity, the magnitude of which is dependent on pile diameter and soil strength (typically for firm or hard soil types). They are used as a connection point for tension leg platform (TLP) tendons and installation often requires the use of a drilling rig or template. Piles can either be driven or screwed into screw or rock. Gravity anchors (i.e. clump weight anchors) are reliant on the mass of anchor (usually made from concrete or rock and/or steel), as well as properties of the soil (friction and shear strength) for lateral loading. Also, suction piles or caissons have been used extensively as foundations.

\section{ARRAYS}

In order to share infrastructure and also to take advantage of the influence of hydrodynamic interactions on power production, close separation distances between MRE devices positioned in arrays (tens of meters) have been proposed. The close proximity between devices means that particular considerations must be made regarding the siting of devices as well as the design of mooring, electrical and hydraulic infrastructure. One such factor is the permitted level of mooring system compliance. This is an important consideration to reduce the risk of mooring line entanglement and device collisions and to allow suitable clearances between the devices for vessel access during installation, maintenance and decommissioning procedures. The separation distance specified in the DNV-OS-E301 Position Mooring guidelines between offshore accommodation units and fixed equipment is necessarily large for the application, but not relevant for MRE devices which are typically unmanned during operation. An alternative and arguably more suitable approach suggested in the DNV-OS-J103 Design of Floating Wind Turbine Structures guideline is to base the separation distance on maximum possible surge or sway displacements during normal operation and if the failure of one mooring line occurs (assuming that the mooring system has built-in redundancy).

MRE arrays may involve 10 s to $>1000$ s of devices distributed over several square kilometres (Ahmadian et al. 2012). For an array of this size it is unlikely that the site will be heterogeneous in terms of sediment or rock type or seabed feature across the site. Thus, a uniform approach to mooring and foundation design may not be suitable and several designs may be required.

To-date the focus of array research has been mainly focused on the impact of array layout or spacing on power production (Bahaj and Myers 2013) but not any impacts on foundations or anchors. Research has recently identified the influence of devices on flow- and wave-fields surrounding wave and tidal energy arrays. For structures positioned on the surface altered flow patterns can result in local scour, with far-field sediment transport effects (i.e. $15 \mathrm{~km}$ from arrays). Across an array it is likely that the loads experienced by moorings and foundations will differ, either due to hydrodynamic interactions or the level of exposure to incident conditions. Shared mooring system infrastructure (i.e. common anchoring points and/or device interconnections) have been suggested as a way of reducing capital costs and to reduce the number and difficulty of installation/decommissioning operations for MRE devices (Figure 6). Such benefits are clearly scalable to large MRE arrays. This concept is not entirely new, with array-type moorings and shared anchor points used for aquaculture systems. Clearly shared anchor and foundation points will experience spatially dependent, multi-directional and time-variant loads and these need to be considered during the foundation or anchor selection and design process.

With the exception of MRE devices attached to a common structure (e.g. Wave Star Energy's Wave Star system and MCT SeaGen), no arrays have been deployed comprising shared mooring or anchoring systems. However, proposed designs include the Karratu (meaning 'square' in Basque) system developed by Tecnalia (Ricci et al. 2012). This concept comprises a network of ropes and cables arranged in square cells the vertices of which are supported by buoys. This network, sitting $5-10 \mathrm{~m}$ below the water surface is catenary moored to the seabed and provides an intermediate mooring system for point absorbers positioned within the cells.

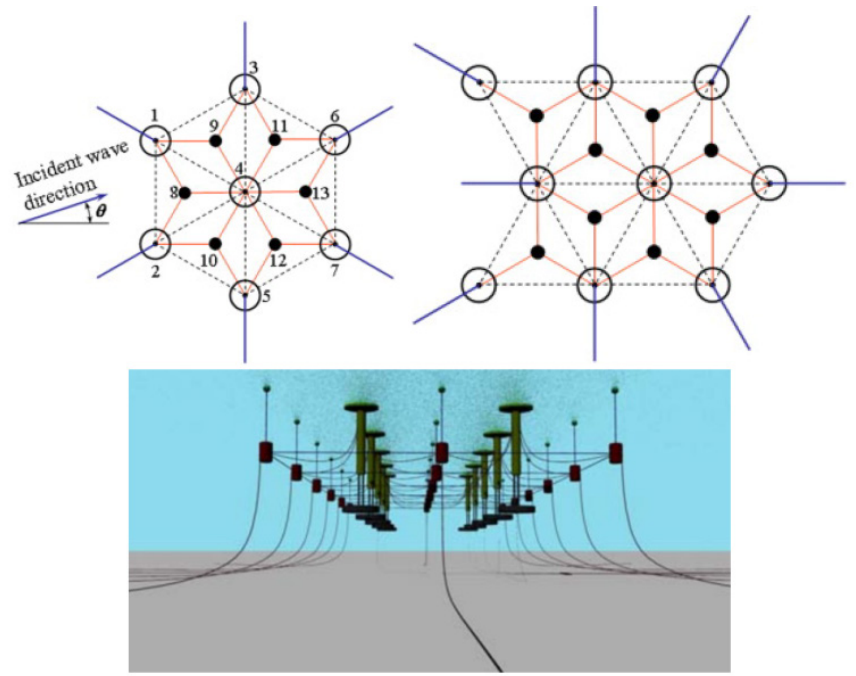

Figure 6. Schematic of proposed array layouts comprising (top left) seven and (top right) nine buoys with interconnecting lines (red) and shared connection points (black dots) Vicente et al. 2009. (bottom) Wave energy array with Karratu mooring system (Ricci et al. 2012) 


\section{CONCLUSIONS}

This article is based on the first deliverable carried out in work package four (WP4) of DTOcean project (The Optimal Design Tools for Ocean Energy Arrays). In this paper, an overview of several key aspects of MRE mooring and foundation design is provided, including mooring and foundation technologies and assessment criteria. Guidance from certification agencies which is used for design and analysis of mooring and foundation systems has been summarized. The transferability of existing approaches to offshore structure design is questionable for MRE devices and more relevant guidance is required that can account for the particularities of MRE arrays. The transferability of existing approaches to offshore structure design is questionable for MRE devices and more relevant guidance is required that can account for the particularities of MRE arrays. For example, hydrodynamic interactions occurring between the devices could result in loads being applied to the array mooring or foundation systems which are different from an individual device. The assessment of a mooring or foundation system needs to incorporate several key aspects, including reliability, economics and environmental impact. It is the role of the DTOcean project to produce an open-source design tool for MRE arrays which will provide solutions which have been assessed by these three criteria.

\section{ACKNOWLEDGEMENT}

The research leading to these results has received funding from the European Community's Seventh Framework Programme for DTOcean Project.

\section{REFERENCES}

Ahmadian R, Falconer R, and Bockelmann-Evans B, (2012). Far-field modelling of the hydro-environmental impact of tidal stream turbines, Renewable Energy, 38(1): p. 107-116.

API, American Petroleum Institute (1996) API RP 2SK: Recommended Practice for Design and Analysis of Stationkeeping Systems for Floating Structures

Astrand K. (2013), Graphical illustration of a wave power plant, Division for Electricity, Uppsala University, http://www.el.angstrom.uu.se

Bahaj A. S. and Myers, L. E. (2013). Shaping array design of marine current energy converters through scaled experimental analysis. Energy, 59: p. 83-94.

Banfield S.J., Casey N.F. and Nataraja R., (2005) Durability of Polyester Deepwater Mooring Rope. Proceedings of the 2005 Offshore Technology Conference, Houston, USA. OTC 17510

Carrell S. (2011), 10MW tidal power station gets Scottish government's approval, http://www.theguardian.com

Cozijn, J.L. and Bunnik, T.H.J. (2004) Coupled mooring analysis for a deep water CALM buoy. Proceedings of the 23rd
International Conference on Offshore Mechanics and Arctic Engineering, Vancouver, Canada

DECC, Department of Energy and Climate Change (2011) Decommissioning of offshore renewable energy installations under the Energy Act 2004

DNV, Det Norske Veritas (2008a) DNV-OSS-312: Certification of Tidal and Wave Energy Converters

DNV, Det Norske Veritas (2008b) DNV-OSS-312: Certification of Tidal and Wave Energy Converters

DNV, Det Norske Veritas (2010) DNV-OS-E301: Position Mooring

EquiMar (2011) Equitable testing and evaluation of marine energy extraction devices in terms of performance, cost and environmental impact

Harris, R.E., Johanning, L. and Wolfram, J. (2004) Mooring systems for wave energy converters: A review of design issues and choices. Proceedings of the 3rd International Conference on Marine Renewable Energy, Blyth, UK

IEC, International Electrotechnical Commission (TBD) TC114: Marine energy - Wave, tidal and other water current converters - Part 10: The assessment of mooring system for marine energy converters (MECs). In-progress

Johanning, L. and Smith, G.H. and Wolfram, J. (2007) Measurements of static and dynamic mooring line damping and their importance for floating WEC devices. Ocean Engineering (2007), 1918-1934

Karimirad, M. (2011) Stochastic Dynamic Response Analysis of Spar-Type Wind Turbines with Catenary or Taut Mooring Systems. PhD Thesis, Norwegian University of Science and Technology

Kenny JP. (2010) Wave Hub Decommissioning Programme

LCICG, Low Carbon Innovation Coordination Group (2012) Technology Innovation Needs Assessment (TINA): Marine Energy Summary Report

Marquis L., Kramer M. and Frigaard P. (2010), First Power Production Results from the Wave Star Roshage Wave Energy Converter International Conference on Ocean Energy, Bilbao, Spain

NFEC, Naval Facilities Engineering Command (2012) SP2209-OCN Handbook for Marine Geotechnical Engineering

Paredes, G. M., Bergdahl, L., Palm, J., Eskilsson, C. and Pinto, F.T. (2013) Station keeping design for floating wave energy devices compared to offshore oil and gas platforms. Proceedings of the 10th European Wave and Tidal Energy Conference, Aalborg, Denmark

Ridge, I.M.L., Banfield, S.J. and Mackay, J. (2010). Nylon Fibre Rope Moorings for Wave Energy Converters. In Proceedings of the OCEANS 2010 conference, Seattle, USA

Ricci, P., Rico, A., Ruiz-Minguela, P., Boscolo, F. and Villate, J.L. (2012) Design, Modelling and Analysis of an Integrated Mooring System for Wave Energy Arrays. Proceedings of the 4th International Conference on Ocean Energy. Dublin, Ireland

SIOCEAN (2013) Ocean Energy: Cost of Energy and Cost Reduction Opportunities

Stallard, T.J., Weller, S.D. and Stansby, P.K. (2009) Limiting heave response of a wave energy device by draft adjustment with upper surface immersion. Applied Ocean Research, 31, (4), pp. 282-289

Vicente, P.C., Falcão, A.F.O., Gato, L.M.C. and Justino, P.A.P (2009) Dynamics of arrays of floating point-absorber wave energy converters with inter-body and bottom slackmooring connections. Applied Ocean Research, 31, (4), pp. 267-281

Vicente, P.C., Falcão, A.F.O. and Justino, P.A.P. (2012) Nonlinear dynamics of a tightly moored point-absorber wave energy converter. Ocean Engineering, 59, pp. 20-36

Weller S.D., Davies, P., Vickers, A.W. and Johanning, L. (2014) Synthetic Rope Responses in the Context of Load History: Operational Performance. Ocean Engineering, 83: p. 111-124 